\title{
Evaluation of phytochemistry and uterotonic activity of root aqueous extract of Uvariodendron anisatum verdec. used in childbirth in Eastern/Central Kenya.
}

\author{
Misonge J.O. ${ }^{1}$ Ogeto J.O. ${ }^{1}$, Sengera G.O. ${ }^{2}$, Mwalukumbi J.M. ${ }^{3}$, Mwaura ${ }^{3}$ A. M. \\ and Juma S.D. ${ }^{3}$ \\ ${ }^{1}$ Mount Kenya University, School of Pharmacy, Department of Pharmacognosy, P.O Box 342-0100, Thika, Kenya \\ ${ }^{2}$ Kisii University, Faculty of Health Sciences, Department of Pharmacy, P.O Box 40200-408, Kisii \\ ${ }^{3}$ University of Nairobi, School of Pharmacy, Department of Pharmacology and Pharmacognosy, P.O Box 30197-0100, \\ Nairobi, Kenya
}

\begin{abstract}
Over $56 \%$ of pregnant women in Kenya deliver at home with the assistance of mainly traditional birth attendants who use herbal remedies to complete the processes of child bearing in both urban and rural communities. The medicines and indigenous knowledge used by traditional birth attendants deserve to be properly validated through scientific scrutiny under conditions mimicking the indigenous methods of use. This work seek to evaluate the phytochemistry and ethnopharmacology of Uvariodendron anisatum Verdeck (Annonaceae) which is used in the management of a variety of conditions including root decoction to ease labor or if the after birth is late or retained. This study is to investigate the phytochemical group of compounds and effects of of Uvariodendron anisatum aqueous root extract on the uterus of Wistar rats. Phytochemical screening was carried out using the accepted standard procedures and the extract was prepared by maceration. In-vitro pharmacological assay was done using doses of $50 \mathrm{mg}, 200 \mathrm{mg}, 400 \mathrm{mg}$ and $800 \mathrm{mg}$. Phytochemical screening revealed the presence of alkaloids, glycosides, tannins, phenols, anthraquinones, steroids, carotenoids, coumarins, tannins, flavonoids, saponins and volatile oils. The extract also demonstrated weak uterine motility which corresponded to the dosage and displayed similar motility as oxytocin at high dose (800 $m g$ ).
\end{abstract}

KEYWORD: Annonaceaea, Oxytocic activity, Maceration, Phytochemical screening

\section{INTRODUCTION}

Over $56 \%$ of pregnant women in Kenya deliver at home with the assistance of mainly traditional birth attendants who use herbal remedies to complete the processes of child bearing in both urban and rural communities (Ken ya National bureau of statistics, 2011). The expectant mothers choose home deliveries for reasons including poor maternity services, negative attitudes of the health workers, cost, accessibility of the health facilities and cultural preferences (USAID-Kenya, 2014). In Kenya complications resulting from reproductive health related conditions such as maternal mortality and morbidity $(14.1 \%)$ account for second in number of the disease burden in Kenya following malaria (19.7\%). The national maternal mortality rates have unacceptably remained high with 488 deaths per 100,000 live births, largely because women do not give birth under the care of skilled health care providers and they die due to preventable conditions including, haemorrhage, obstracted labor, complications of unsafe abortion and high blood pressure (Health policy project, 2014). In the efforts to meet the Millenium development goal number five of reducing maternal mortalities by 75\% by the year 2015 and Kenya Vision 2030. (The Millenium Development Goals, 2013). The traditional medicines and indigenous knowledge used by traditional birth attendants deserve to be documented and the claims properly validated through scientific scrutiny under conditions mimicking the indigenous methods of use (GOK, 2014). This work seek to evaluate the phytochemistry and ethnopharmacology of Uvariodedron anisatum Verdeck (Annonaceae) shrub which is used ethnomedically in the management of a variety of conditions including root decoction to ease labor or if the after birth is late or retained. The objective of this study is to investigate the phytochemical group of compounds and effects of Uvariodedron anisatum aqueous root extract on the uterus of Wistar rats with an aim of scientific validation of the ethnomedicinal use of this particular plant in the management of child bearing process.

Uvariodendron anisatum belong to the genus Uvariodendron which is among the seventeen well known genera of the family annonaceae family found in Kenya. The genera also consist other species in Kenya like Uvariodendron gorgonis, Verdc. and Uvariodendron kirkii, Verdc., (Beentje, 1994) while other species occur around the world and may be include Uvariodendron connivens (Benth.) R.E.Fries, Uvariodendron 
fuscum, (Benth.) R.E.Fries, Uvariodendron giganteum, (Engl.) R.E.Fr. Uvariodendron occidentale, Le Thomas, Uvariodendron oligocarpum, Verdc. Uvariodendron pycnophyllum, (Diels) R.E. Fr. and Uvariodendron usambarense, R.E. Fr. (uttp://en.wikipedia.org/wiki/uvariodendron. 2012). Uvariodendron usambarense, R.E.Fr. and Uvariodendron pycnophyllum are endemic to Tanzania (Kihampa et al., 2009).

The species Uvariodendron anisatum is used ethnomedically in Kenya in management of a variety of conditions including root decoction to ease labour or if the after birth is late and also root infusion for impotence in men (Gachathi, 2007). The Embu and Mbeere people of Kenya also use the root tuber concoction for the management of breast cancer, diabetes, snake-bite and calf-rejection in traditional veterinary medicine (Kareu, 2007). The wood is used for walking sticks and axe handles (Beentje, 1994).

\section{MATERIAL AND METHODS}

The plant parts (roots, leaves and fruits of $U$. anisatum) were collected from Kiangombe forest (Mbeere district) and a voucher specimen of the plant was authenticated at the Herbarium section of the National Museums of Kenya in Nairobi where a voucher specimen was deposited and its duplicate was deposited in the Herbarium at the department of Pharmacognosy, School of Pharmacy of Mount Kenya University with voucher specimen number "UAO-2014". The roots of $U$. anisatum were air-dried, ground and $100 \mathrm{~g}$ were extracted by maceration for 48 hours using $1000 \mathrm{ml}$ of distilled water in a $2000 \mathrm{ml}$ conical flask. The extract was filtered and then freeze-dried to afford the dry powders that was weighed and stored in a freezer at $-20^{\circ} \mathrm{C}$ until further use.

\section{PHYTOCHEMICAL SCREENING}

The powders of roots and leaves were tested for the presence of bioactive compounds using standard methods as illustrated in table 2 (Harbone, 1976; Houghton, 1998; Trease and Evans, 2008).

Table 2: Phytochemical tests of various parts of Uvariodendron anisatum.

\begin{tabular}{|c|c|c|c|}
\hline \multicolumn{2}{|l|}{ Phytochemicals } & \multicolumn{2}{|l|}{ Procedure } \\
\hline $\begin{array}{l}\text { Gums } \\
\text { and Mucilages }\end{array}$ & $\begin{array}{l}\text { Gums and Mucilages } \\
\text { Test }\end{array}$ & $\begin{array}{l}0.5 \mathrm{ml} \text { of extract }+5 \mathrm{ml} \text { distilled water }+25 \mathrm{ml} \text { of } \\
\text { absolute alcohol were prepared }\end{array}$ & $\begin{array}{l}\text { Cloudy or } \\
\text { white ppt }\end{array}$ \\
\hline \multirow[t]{2}{*}{ Alkaloids } & Mayer,s test & $\begin{array}{l}\text { To a } 1 \mathrm{ml} \text { filtrate, few drops of Mayer's reagent } \\
\text { were added }\end{array}$ & White ppt \\
\hline & Dragendorff test & $\begin{array}{l}\text { To a } 2 \mathrm{ml} \text { of filtrate, } 2 \mathrm{ml} \text { of dragendorff reagent } \\
\text { were added }\end{array}$ & Red ppt \\
\hline \multirow[t]{4}{*}{ Glycosides } & $\begin{array}{l}\text { Kedde test - } \\
\text { Unsaturated lactone } \\
\text { ring }\end{array}$ & $\begin{array}{l}\text { To } 0.5 \mathrm{ml} \text { of extract }+2 \text { drops of Kedde reagent } \\
\text { were added }(\mathrm{DNB}+\mathrm{NaOH})\end{array}$ & $\begin{array}{l}\text { Purple } \\
\text { colour }\end{array}$ \\
\hline & $\begin{array}{lr}\text { Borntrager's } & \text { test- } \\
\text { test } & \text { for } \\
\text { anthraquinone } & \\
\text { glycoside } & \end{array}$ & $\begin{array}{l}\text { About } 5 \mathrm{~g} \text { (Powder) }+ \text { in } 5 \mathrm{ml} \text { of } \mathrm{H}_{2} \mathrm{SO} 4 \text { was boiled } \\
\text { for } 5 \mathrm{~min} \text {. Filtered and cooled and then to the } \\
\text { extract equal vol. of carbon tetrachloride was } \\
\text { added and shaken. The organic layer was separated } \\
\text { and shaken with a few drops of dilute ammonia. }\end{array}$ & $\begin{array}{l}\text { A rose pink } \\
\text { to red } \\
\text { colour in } \\
\text { the } \\
\text { ammoniacal } \\
\text { layer }\end{array}$ \\
\hline & $\begin{array}{l}\text { Modified } \\
\text { Borntrager's test- } \\
\text { anthraquinone } \\
\text { glycoside }\end{array}$ & $\begin{array}{l}\text { Extraction as above except } 5 \% \mathrm{FeCl}_{3} \text { were added } \\
\text { during extraction with dilute ammonia. }\end{array}$ & As a bove \\
\hline & Froth test - Saponins & $\begin{array}{l}\text { A bout } 0.5 \mathrm{~g} \text { (powdered) }+5 \mathrm{ml} \text { water. The } \\
\text { mixture was shaken and left to stand. }\end{array}$ & $\begin{array}{l}\text { Persistent } \\
\text { frothing }\end{array}$ \\
\hline Tannins/ phenols & Ferric chloride test & $\begin{array}{l}\text { A bout } 1 \mathrm{~g} \text { (powder) was boiled in } 10 \mathrm{ml} \text { of water } \\
\text { for } 5 \mathrm{~min} \text { in a water bath, extract was filtered to } 2\end{array}$ & $\begin{array}{l}\text { brown- } \\
\text { green ppt }\end{array}$ \\
\hline
\end{tabular}




\begin{tabular}{|l|l|l|l|}
\hline & & $\begin{array}{l}\text { portions and cooled. To one portion 3 drops of } \\
\text { ferric chloride solution were added and to the other } \\
\text { portion } 1 \mathrm{ml} \text { of lead subacetate was added. }\end{array}$ & $\begin{array}{l}\text { with } \mathrm{FeCl}_{3} \\
\& \text { a creamy- } \\
\text { brown ppt } \\
\text { with lead } \\
\text { subacetate }\end{array}$ \\
\hline Phytosteroids & Salkowski test & $0.5 \mathrm{ml}$ of extract $+1 \mathrm{ml}$ of Conc. $\mathrm{H}_{2} \mathrm{SO} 4$ & $\begin{array}{l}\text { Wine red } \\
\text { colour }\end{array}$ \\
\hline Triterpenes & $\begin{array}{l}\text { Liberman- } \\
\text { Burchard's test }\end{array}$ & $\begin{array}{l}0.5 \mathrm{ml} \text { of extract } \text { few drops of acetic anhydride+ 1 } \\
\text { ml of Conc. } \mathrm{H}_{2} \mathrm{SO} 4\end{array}$ & $\begin{array}{l}\text { Red ring at } \\
\text { the junction }\end{array}$ \\
\hline Coumarins & Ferric chloride test & $\begin{array}{l}\text { About } 1 \mathrm{~g} \text { (Powder) + in } 10 \text { ml of ethanol was } \\
\text { boiled for } 5 \text { min in a waterbath, extract was filtered } \\
\text { and then cooled. To 2 ml of extracts a few drops of } \\
\text { alcoholic Ferric chloride solution was added }\end{array}$ & $\begin{array}{l}\text { Deep green } \\
\text { ppt turns } \\
\text { yellow on }+ \\
\text { conc. nitric } \\
\text { acid }\end{array}$ \\
\hline Volatile oils & Smell test & $\begin{array}{l}5 \mathrm{mg} \text { of drug powder was crushed between the } \\
\text { thumb and forefinger }\end{array}$ & $\begin{array}{l}\text { Strong } \\
\text { odour }\end{array}$ \\
\hline Flavonoids & $\begin{array}{l}\text { Test with Ammonia } \\
\text { vapour }\end{array}$ & $\begin{array}{l}\text { A bout } 1 \mathrm{~g} \text { (powder) was boiled in 10 ml 70\% } \\
\text { ethanol for } 5 \text { min, extract was filtered and cooled. } \\
\text { A filter paper was dipped into the alcoholic } \\
\text { solution and then exposed to ammonia vapour. }\end{array}$ & $\begin{array}{l}\text { Yellow spot } \\
\text { on the filter } \\
\text { paper }\end{array}$ \\
\hline
\end{tabular}

\section{Preparing and Mounting of the rat uterus for uterotonic activity}

A young non-pregnant virgin wistar rat weighing 151 grams was pretreated with $2 \mathrm{mg}$ of diethylstilboestrol 24 hours prior to the actual experiment. The rat was sacrificed humanely by spinal dislocation. The abdominal cavity was opened and the two horns of the uterus carefully removed into a petri dish containing De jalons ringer solution. The horns of the uterus were carefully separated from the animal just below the ovaries and were cleaned and any extraneous fat and connective tissues removed. The horns were then separated at the bifurcation and yielded two uterus preparations (Maud Kamatenesi et al., 2005). About 3 $\mathrm{cm}$ piece of the uterus was mounted in an organ bath containing De-jalons physiological salt solution composed of $\mathrm{Nacl}(9 \mathrm{~g} / \mathrm{l}), \mathrm{NaHCO}_{3}(0.5 \mathrm{~g} / \mathrm{l})$, D. Glucose $(0.5 \mathrm{~g} / \mathrm{l}), \mathrm{KCL}(0.402 \mathrm{~g} / \mathrm{l}), \mathrm{CaCl}_{2} \times 2 \mathrm{H}_{2} \mathrm{O}(0.08 \mathrm{~g} / \mathrm{l})($ Catherine $e t$ al., 2012).

The tissue was aerated with $95 \%$ oxygen and $5 \%$ carbon dioxide and the temperature was maintained at $37^{\circ} \mathrm{C}$ and the solution $\mathrm{PH}$ of 7.4 for a period of 30 to 40 minutes to normalize before adding the plant crude extracts and the standard drug (oxytocin 0.1 IU) so that spontaneous activity could be deduced (Maud Kamatenesi et al., 2005; Falodun et al., 2006).

\section{Preparation of aqueous extract}

The stock solution of the extract was prepared by making $100 \mathrm{mg} / \mathrm{ml}$ and $1000 \mathrm{mg} / \mathrm{ml}$. The $1 \mathrm{ml}$ syringe with 0.01 graduations was used to administer $0.5 \mathrm{ml}$ from the $100 \mathrm{mg} / \mathrm{ml}$ stock solution and $0.2 \mathrm{ml}, 0.4$ $\mathrm{ml}$ and $0.8 \mathrm{ml}$ from the $1000 \mathrm{mg} / \mathrm{ml}$ stock solution respectively into a $20 \mathrm{ml}$ organ bath with the tissue. The volumes administered represented doses of $50 \mathrm{mg}, 200 \mathrm{mg}, 400 \mathrm{mg}$, and $800 \mathrm{mg}$ respectively. The Ugobasile physiological recording machine was connected to the transducer and then to the tisuue with writing pen and chart in place so that contractions were recorded on the recording chart as shown in graph 1.

The tissue was washed with De Jalons ringer solution 3 times after every administration of a drug dose or standard of drugs and recording was done before another drug dose was introduced. The time of tissue washing varied based on the behavior of the drug on the tissue. The washed tissue in the organ bath was left to normalize before administration of another drug dose. 


\section{RESULTS AND DISCUSSION}

\section{Phytochemical composition of Uvariodendron anisatum}

The aqueous extraction of U.anisatum roots yielded 5.6\%. This implies that organic solvent extracts for the secondary metabolites may be explores for better yields, though it is well known that in traditional healing the water extract is the primary source of the U. anisatum for medicinal use, Table 2 shows the phytochemicals identified in the plant's roots and leaves extracts as alkaloids, glycosides, tannins, phenols, anthraquinones, phyteroids, carotenoids, coumarins, flavonoids, saponis and volatile oils. The tannins and flavonoids have been reported to affect calcium availability for the contraction of uterine smooth muscle and cardiac muscle and also cardiac glycosides have been shown to affect the uterus of various animal species (Catherine et al., 2012; Omodamiro et al., 2012).

Table 2. A table showing the phytochemicals screening results of the root and leave powders

\begin{tabular}{|llc|}
\hline Phytochemicals & \multicolumn{2}{l|}{ Part of the plant } \\
\cline { 2 - 3 } & Leaves & Root \\
\hline Alkaloids & ++ & ++ \\
Glycosides & ++ & + \\
Saponins & + & + \\
Tannins & ++ & + \\
Phenols & + & + \\
Anthraquinones & ++ & ++ \\
Steroids & ++ & ++ \\
Carotenoids & + & ++ \\
Coumarins & + & + \\
Flavonoids & + & ++ \\
Volatile oils & ++ & + \\
\hline
\end{tabular}

+ - Present in relatively small amounts, ++ - Present in relatively moderate

amounts, +++ - Present in relatively high amounts

Uterotonic activity of Uvariodendron anisatum root extract on the rat uterus : The aqueous extracts of of $U$. anisatum roots dissolved completely in the De jalons solution. Uvariodendron anisatum at $200 \mathrm{mg} / \mathrm{ml}, 400$ $\mathrm{mg} / \mathrm{ml}$ and $800 \mathrm{mg} / \mathrm{ml}$ showed rat uterine contraction activity (Graph 1).The rat uterus tissue was used in the ethnopharmacological screening because $U$. anisatum herbal remedies are used in stimulating child birth traditionally. The smooth muscle of the rat uterus was the point of contact for this herbal drugs experimentation because of its high sensitivity among other laboratory animals. The aqueous extracts of $U$. anisatum contracted and increased the uterine motility. In the interpretation of the results, normal motility is the baseline for that particular tissue. Standard drugs (Oxytocin) was used as the controls of the set up. 


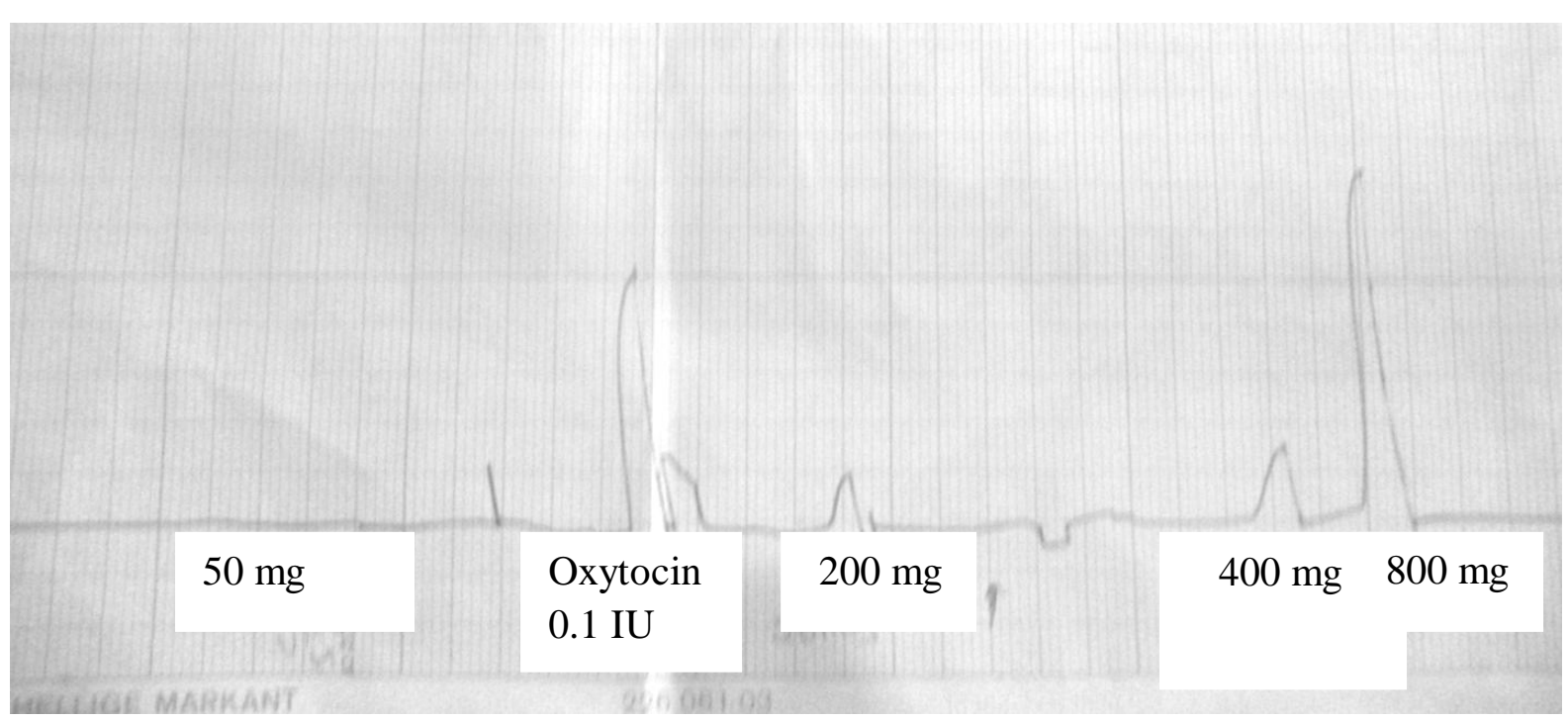

\section{Graph 1 The effects of Uvariodendron anisatum on the Rat uterine contractions}

From graph 1, injection of $50 \mathrm{mg}$ from the $100 \mathrm{mg} / \mathrm{ml}$ solution of aqueous plant extracts to the organ bath showed no uterotonic activity. The $200 \mathrm{mg}$ of the plant extracts produced contractions to the rat uterus. The 400 $\mathrm{mg}$ of the plant extract showed uterotonic activity which was twice powerful as that produced by $200 \mathrm{mg} / \mathrm{mL}$ of the plant extract. Injection of $800 \mathrm{mg}$ of the aqueous plant extracts produced uterotonic activity almost equivalent to that produced by Oxytocin (Standard drug). Though the contraction of the extract were not as intense as those of the standard they indicate dose dependent activity and exhibit comparable results with the extracts of a plant of similar family, Xylopia aethiopica (annonaceae).

\section{CONCLUSION AND RECOMMENDATION}

Phytochemical screening results of this study indicates this plant (Uvariodendron anisatum) contain more than one group of secondary metabolites and this may suggestively be the reason for its elaborate usage in ethnomedicine. The observation of of the uterotonic activity of the root aqueous extract on the isolated rat uterus justify the traditional use of the plant by traditional birth attendants for removing the afterbirth if it get retained when assisting women who are giving birth. It is recommended that further work be explored to isolate compounds responsible for the uterotonic activity that may be leads for the development of more save drugs to be used during delivery. These findings also warrant studies on mechanisms of action and toxicity of the plant extracts, fractions and isolated compounds.

\section{ACKNOWLEDGEMENT}

The author greatly acknowledges Mount Kenya University for the Vice Chancellor's grant (number 0054 of the year 2012/2013) that enabled this work this far.

\section{REFERENCES}

[1]. Bafor, E.E., Omogbai, E.K., Ozolua, R.I. (2009). Evaluation of the Uterotonic Activity of Ficus exasperata Vahl (Moraceae). Research Journal of Medicinal Plant 3, 34-40.

[2]. Beentje H.J. Kenya Trees, Shrubs and Lianas. National Museums of Kenya, Nairobi, 1994 p.53.

[3]. Catherine Kaluwa Kaingu, Jemimah Achieng Oduma and Titus Kanui (2012). Preliminary investigation of contractile activity of Ricinus communis and Euclea divinorum extracts on isolated rabbit uterine strips. Journal of ethnopharmacology, 142:496-502)

[4]. Falodun A., Nworgu C.A.M. and Ikponmwonsa M.O. (2006). Phytochemical components of Hunteria umbellate (K. Schum) and its effects on isolated non-pregnant rat uterus in oesterus.Pakstan Journal of Pharmaceutical Sciences, 19(13):256-258.

[5]. Gachathi Murugu Norman Francis (2007). Kikuyu botanical dictionary. Revised edition. A guide to plant names, uses and cultural values. Tropical botany Nairobi, Kenya.

[6]. Government of Kenya (2014). The Kenya Health Bill

[7]. Harbone J.B.(1976). Phytochemical methods. A guide to modern techniques of plants analysis. Chapman and Hall Ltd, London.

[8]. Houghton P.J. and Raman Amala (1998). Laboratory handbook for the fractionation of natural extracts. Chapman Hall. Lomdon [9]. http://en.wikipedia.org/wiki/uvariodendron_anusatum. May 25, 2012.

[10]. Kareru P.G.. Kenji G.M., Gachanja A.N., Keriko J.M. and Mungai G. (2007). Traditional medicines among the Embu and Mbeere people of Kenya. African Journal of Traditional, Complementary and Alternative Medicine, 4 (1): 75-86.

[11]. Kenya National bureau of statistics (2011). Kenya County fact sheets. 
[12]. Kihampa C., Joseph C.C, Nkunya H.H.M., Magesa S.M., Hassanali A.. Heydenreich M. and Kleinpeter E. (2009). Lavicidal and IGR activity of extracts of Tanzanian plants against malaria vector mosquitoes. Journal of Vector Borne diseases.(46): 145152.

[13]. Maud Kamatenesi- Mugisha, Hannington Oryem- Origa, Olwa-Odyek and Dominic W. Kamawiti (2005). Ethnopharmacological screening of Vernonia amygdalina and Cleome gynandra traditionally used in childbirth in Western Uganda. The proceeding of the 11th NAPRECA Symposium on natural products and drug discovery: 9-12 Antananarivo. Madagascar.

[14]. Omodamiro O.D., Ohaeri O.C. and Nweke I.N. (2012). Oxytocic effect of aqueous, ethanolic, n-hexane and chloroform extracts of Xylopia aethiopica (annonaceae) and Ocimum gratissium (Labiatae) on guinea pig uterus. Asian Journal of Plant Science and Research, 2(1): 73-78

[15]. Trease GE and Evans WCA (2008). Textbook of Pharmacognosy $15^{\text {th }}$ ed., English Language Book Society, Bailierie Tindall, London, pp. $386-480$.

[16]. The Millenium Development Goals (2013). Executive summery assessing the progress in Africa towards the Millenium development goals.

[17]. USAID/KENYA (2014). Maternal and Newborn Health care in Kenya, Policy changes to benefit women: Health policy project. 